\title{
The Dave Spencer Site on Middle Lilly Creek in Camp County, Texas
}

Timothy K. Perttula

Heritage Research Center, Stephen F. Austin State University

Bo Nelson

Heritage Research Center, Stephen F. Austin State University

Follow this and additional works at: https://scholarworks.sfasu.edu/ita

Part of the American Material Culture Commons, Archaeological Anthropology Commons, Environmental Studies Commons, Other American Studies Commons, Other Arts and Humanities Commons, Other History of Art, Architecture, and Archaeology Commons, and the United States History Commons

Tell us how this article helped you.

This Article is brought to you for free and open access by the Center for Regional Heritage Research at SFA ScholarWorks. It has been accepted for inclusion in Index of Texas Archaeology: Open Access Gray Literature from the Lone Star State by an authorized editor of SFA ScholarWorks. For more information, please contact cdsscholarworks@sfasu.edu. 


\section{The Dave Spencer Site on Middle Lilly Creek in Camp County, Texas}

Creative Commons License

(c) $($ ) (9)

This work is licensed under a Creative Commons Attribution-NonCommercial 4.0 International License 


\title{
The Dave Spencer Site on Middle Lilly Creek in Camp County, Texas
}

\author{
Timothy K. Perttula and Bo Nelson
}

\section{INTRODUCTION}

The Dave Spencer site (41CP497) is an ancestral Caddo site in the Middle Lilly Creek valley in southwestern Camp County, Texas (Figure 1). It is situated on a lower upland ridge slope (350-355 feet amsl) about $200 \mathrm{~m}$ south of the current channel of Middle Lilly Creek. This creek is an eastward-flowing stream in the Little Cypress Creek basin.

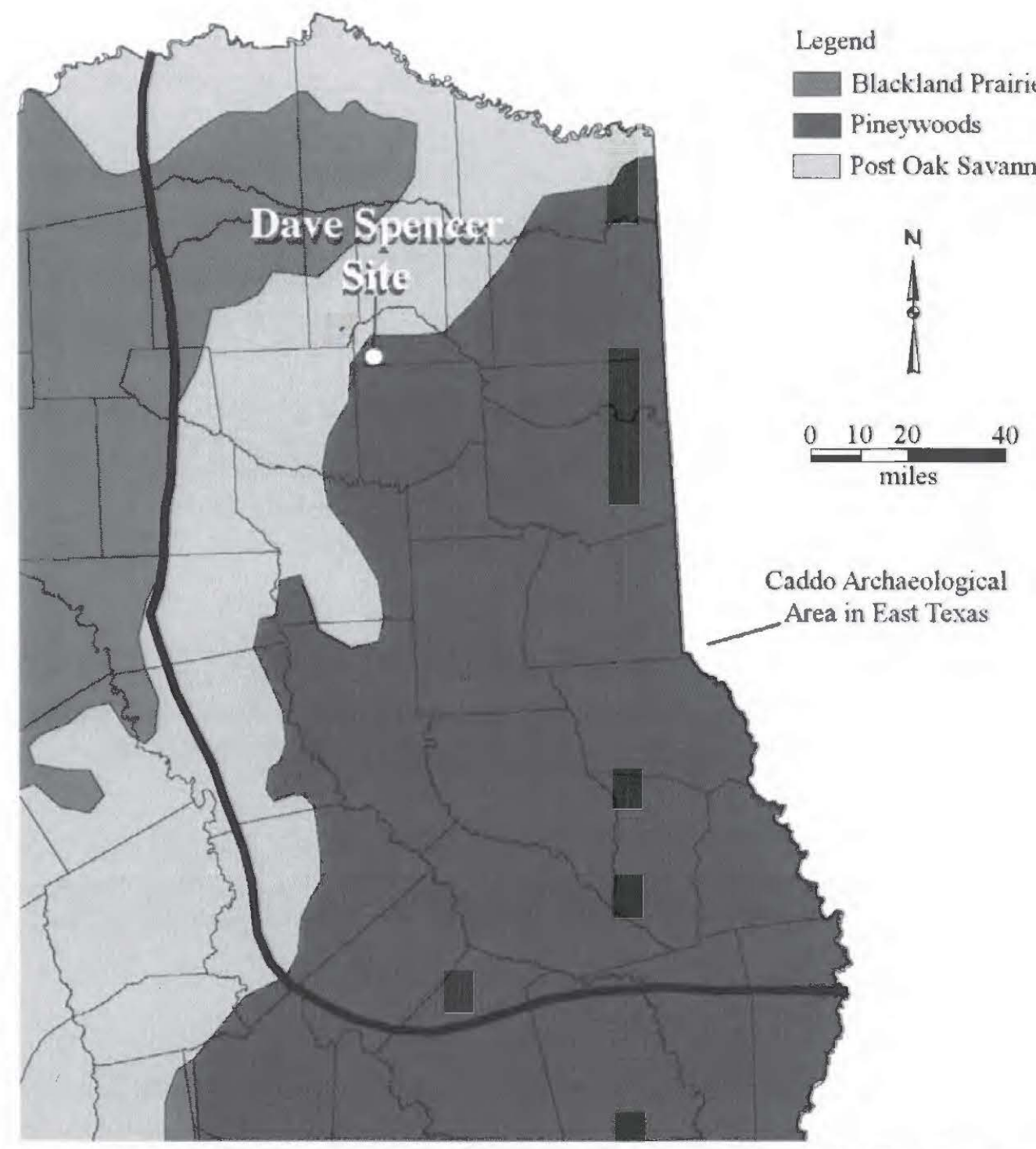

Figure 1. The location of the Dave Spencer site in Camp County in the East Texas Pineywoods. Figure prepared by Lance Trask. 
Robert L. Turner, Jr. identified the site some years ago, and obtained a surface collection from it. The analysis of the artifacts in that surface collection are the subject of this article.

\section{ARTIFACT COLLECTION}

The surface collection made by Turner includes both lithic and ceramic artifacts, but primarily the latter.

\section{Lithic Artifacts}

The lithic artifacts from the Dave Spencer site consist of three pieces of lithic debris from stone tool manufacture and maintenance activities. This includes a cortical piece of heat-treated novaculite and two pieces of local quartzite. One of the quartzite pieces had a stream-rolled cortical surface, and has been heattreated.

\section{Ceramic Sherds}

There are 74 ceramic sherds in the Dave Spencer site surface collection, 53 plain sherds and 21 decorated sherds. The plain to decorated sherd ratio is 2.52 . Approximately $85 \%$ of the sherds are from grog-tempered vessels, and the other $15 \%$ are tempered with crushed and burned bone.

\section{Plain Sherds}

One of the 53 plain sherds is from a bottle, and the other plain sherds include 42 body sherds and 10 base sherds. Approximately $13 \%$ of the plain sherds are from bone-tempered vessels.

\section{Utility Ware Sherds}

The utility wares $(n=10)$ at the Dave Spencer site include both incised and punctated vessels. Twenty percent of the utility wares are from bone-tempered vessels. Three body sherds, all grog-tempered, have parallel incised lines. The remainder of the utility wares are from punctated vessels. One bone-tempered rim has a row of tool punctations at the lip, and there are four body sherds with rows of tool punctations. Two body sherds are covered with fingernail punctations.

\section{Fine Ware Sherds}

The fine ware sherds include sherds from red-slipped bowls $(n=3)$ and eight engraved rim and body sherds from carinated bowls and a bottle; $18 \%$ of the sherds are from bone-tempered vessels. The red-slipped sherds are from grog-tempered vessels, and they either have a red slip on both sherd surfaces $(n=2)$ or only on the exterior surface.

The engraved carinated bowl sherds have simple geometric decorative elements: diagonal lines $(n=2)$, a straight line $(n=3)$, parallel lines $(n=1)$, and vertical lines $(n=1)$. The engraved lines are finely drawn, not broad in execution. The one engraved bottle sherd has a narrow zone filled with diagonal hatched lines; a red ochre-rich pigment has been rubbed in the engraved design.

\section{SUMMARY AND CONCLUSIONS}

The Dave Spencer site is an ancestral Caddo site, probably a domestic settlement, in the Middle Lilly Creek valley in the Little Cypress Creek basin in the East Texas Pineywoods. A small surface collection has been obtained from the site by Robert L. Turner, Jr. Other than lithic debris, the surface collection contains 
a sample of plain ware sherds, utility ware (incised and punctated jars), and fine ware (red-slipped and engraved carinated bowls and bottles) sherds from grog-tempered (85\%) and bone-tempered (15\%) vessels.

Although none of the decorated sherds can be definitely identificd as belonging to one of the current East Texas Caddo ceramic types (e.g., Suhm and Jelks 1962), it is possible to determine the temporal affiliation of the Dave Spencer site by comparison with other known and/or radiocarbon-dated sites in the Big and Little Cypress Creek basins (see Perttula and Ellis 2012). In the Big and Little Cypress Creek basins, pre-A.D. 1200 Caddo sites do not have brushed utility ware ceramics. Utility wares are dominated by punctated, incised, and punctated-incised elements and motifs, and various kinds of engraved fine wares. There are no brushed sherds in the Dave Spencer ceramic assemblage, which strongly suggests it was occupied sometime prior to ca. A.D. 1200.

The pre-A.D. 1200-1250 East Texas Caddo sites in the Big and Little Cypress Creek basins in East Texas comprise a distinctive assemblage of relatively simple straight and geometric designs on fine wares and utility wares, and curvilinear engraved and excised designs on bottles; the Dave Spencer site belongs to this cultural tradition. In none of the sites that date to this time period that have been well-documented is brushed utility ware at all common (accounting for less than $4 \%$ of all the decorated sherds in any one assemblage), and in most cases, brushed utility wares are not a feature of these assemblages (Perttula and Ellis 2012:Table 8-24). It is apparently only after ca. A.D. 1260 that brushed utility wares make their appearance in East Texas Caddo assemblages, and its manufacture and use is one of the ceramic signatures of the Middle Caddo period in many sites in both the Big and Little Cypress Creek stream basins.

\section{REFERENCES CITED}

Perttula, T. K. and L. W. Ellis

2012 The Hickory Hill Site (4ICP408): Archeological Investigations at a Middle Caddo Site in the Little Cypress Creek Basin in East Texas. Document No. 120055. Atkins Group, Austin.

Suhm, D. A. and E. B. Jelks (editors)

1962 Handbook of Texas Archeology: Type Descriptions. Special Publication No. 1, Texas Archeological Society, and Bulletin No. 4, Texas Memorial Museum, Austin. Reprinted in 2009, Gustav's Library, Davenport, lowa. 